\title{
An Analysis of the "National Security Interest" \\ Provision in terms of Section 18A of the Competition \\ Act 89 of 1998
}

\section{P.E.R}

Pioneer in peer-reviewed,

open access online law publications

Author

Simbarashe Tavuyanago

Affiliation

University of the Free State,

South Africa

Email Tavuyanagos@ufs.ac.za

Date Submission

10 February 2019

Date Revised

26 February 2021

Date Accepted

26 February 2021

Date published

9 April 2021

Editor Prof A Gildenhuys

How to cite this article

Tavuyanago S "An Analysis of the "National Security Interest"

Provision in terms of Section 18A of the Competition Act 89 of 1998" PER / PELJ 2021(24) - DOI http://dx.doi.org/10.17159/17273781/2021/v24i0a6031

Copyright

http://dx.doi.org/10.17159/1727-

3781/2021/v24i0a6031

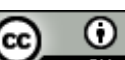

O

\begin{abstract}
This contribution examines the implications of the "national security provision" in terms of section 18A of the Competition Act 89 of 1998 as inserted by section 14 of the Competition Amendment Act 18 of 2018. The effect of section 18A is that it confers upon the President of the Republic of South Africa power to appoint a national security committee whose mandate is to investigate mergers involving a foreign acquiring firm and determine whether such a merger would pose a threat to the "national security interests". The contribution highlights the possible challenges that the insertion of section 18A may precipitate. It argues that while the protection of national security interests is imperative, it is however not the goal of competition policy to regulate broader national security policy. In making the argument, cognisance is taken of the fact that where a gap exists in policy, legislative amendments may be used as stopgap mechanisms. The paper investigates the treatment of national security interests in foreign jurisdictions in a bid to establish whether the provision is in line with international best practice and whether any lessons may be drawn therefrom.
\end{abstract}

\section{Keywords}

Competition law; national security interests; merger regulation; investment screening. 


\section{Introduction}

Section 18A of the Competition Act confers on the President of the Republic of South Africa the power to create a national security committee whose mandate is to determine whether the implementation of a merger involving a foreign acquiring firm may have an adverse effect on the "national security interests" of South Africa. ${ }^{1}$ Section $18 \mathrm{~A}$ empowers the national security committee to prohibit, conditionally approve or unconditionally approve a merger involving a foreign acquiring firm based on its determination of the threat to "national security interests". While the term "national security interests" in itself is not defined, a list of factors that must be taken into consideration when determining national security interests is provided. ${ }^{2}$ The amendment raised concerns as some observers thought that the wording of section $18 \mathrm{~A}$ is vague and open to potential abuse. ${ }^{3}$ Consequently, this paper seeks to examine the implications of the proposed national security provision, to determine whether the provision is in line with the goals of competition policy, and to determine whether South Africa through the introduction of section $18 \mathrm{~A}$ is in line with international best practice.

This paper utilises a comparative analytical approach by critically examining the national security provision, considering national legislation, foreign legislation and the scholarly work of numerous writers. The paper's primary focus will be on an examination of the ramifications of the introduction of a national security clause through section 18A. The paper also seeks to establish whether South Africa is in line with international best practice in its treatment of "national security interests" in the realm of merger regulation and whether competition law is the appropriate tool to achieve the safeguarding of "national security interests". To achieve this, the paper will first, briefly outline the legal framework for the review and control of mergers in South Africa prior to the amendment in order to contextualise the introduction of section 18A. Secondly, it will examine the introduction of "national security interests" into the South African merger control regime as well as the implications thereof. Thirdly, the paper will draw from foreign jurisdictions through a comparative analysis of the treatment of national security interests in the selected jurisdictions. This will be done in an effort to establish international best practice and determine whether South Africa

\footnotetext{
Section 18A inserted into the Competition Act 89 of 1998 (the Competition Act) by s 14 of the Competition Amendment Act 18 of 2018.

Section 18A(4) of the Competition Act.

Helen Suzman Foundation 2018 https://hsf.org.za/publications/hsfbriefs/parliamentary-submission-competition-amendment-bill-2018. Also see Wood 2018 https://www.bowmanslaw.com/insights/competition/the-competition-amendment-bill-2018-introduced-in-parliament-national-security-considerations/.
} 
is in line with the same. Lastly, the paper will conclude and offer recommendations.

\section{Framework for merger regulation}

A merger occurs when one or more firms directly or indirectly acquire or establish direct or indirect control over the whole or part of the business of another firm. ${ }^{4}$ In terms of Chapter 3 , the competition authorities are mandated to investigate and regulate mergers. ${ }^{5}$ The competition authorities comprise the Competition Commission, the Competition Tribunal and the Competition Appeal Court. ${ }^{6}$ There exists a hierarchy of authority where decisions of the Competition Commission are appealable to the Competition Tribunal, while the Tribunal's decisions are also appealable to the Competition Appeal Court. ${ }^{7}$

Prior to the amendment, when considering a merger that had been notified to the authorities the Commission and/ or the Tribunal had to conduct a twopronged test to determine whether such a merger should be approved or not. The Commission or Tribunal, as the case may be, would first have to consider competition factors. ${ }^{8}$ These are purely economic aspects with the key question being whether or not the implementation of the merger would substantially lessen competition. This is in line with the international approach to merger regulation, as the vast majority of countries that establish a merger control regime choose to adopt a primarily competitionbased approach to merger assessments. ${ }^{9}$ Subsequent to the consideration of competition factors, the Commission or the Tribunal would then consider public interest factors. ${ }^{10}$ The public interest test is an assessment of whether there is any interest that the public may derive from the merger. ${ }^{11}$ The dual pronged assessment finds justification in the need to address inequalities of the past with regard to active participation in the economy, among others. ${ }^{12}$ This justification is also echoed by Hartzenberg, ${ }^{13}$ who notes:

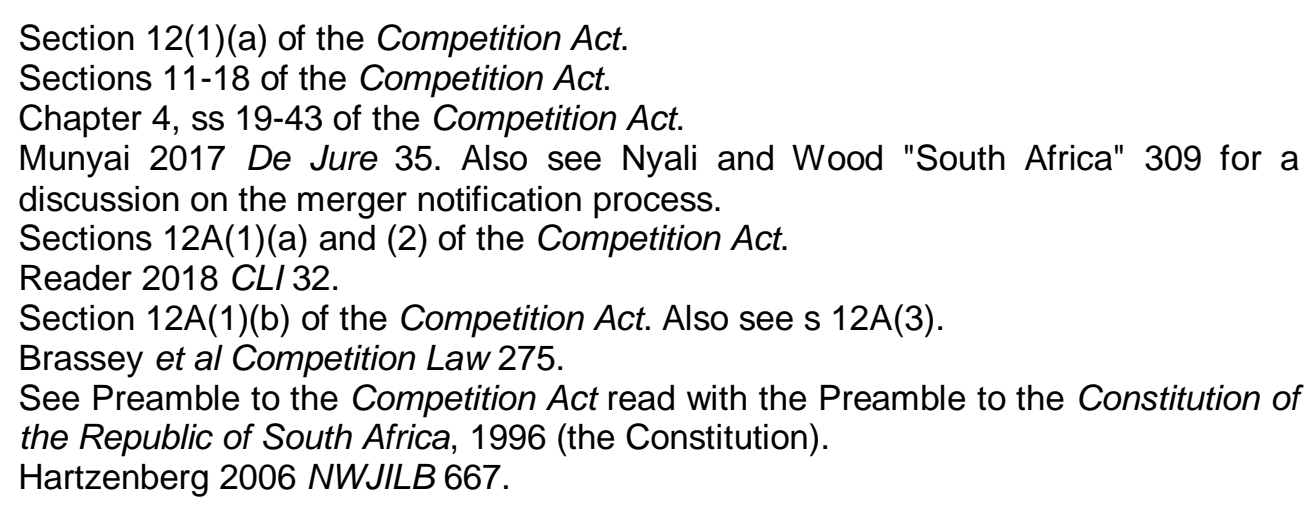


It was clear that a robust competition law would only be politically possible if the law specifically addressed public interest concerns. The core focus of economic efficiency had to be tempered by a strong emphasis on development.

The competition and public interest factors must be considered independent of each other. ${ }^{14}$ The effect of this independence is described by Sutherland ${ }^{15}$ as follows:

The public interest test unlike the efficiency defence has a 'Janus-faced' quality. It can save a merger that would otherwise have been prohibited on pure competition grounds.

Tavuyanago ${ }^{16}$ summarises merger assessment thus:

Even though a merger may not have an adverse effect on competition, it still has to be reviewed on public interest grounds as it may be prohibited on that assessment. Conversely, the public interest inquiry may also work to resuscitate a merger that is otherwise anti-competitive. This makes the test mandatory because of the dichotomy of possible outcomes.

This paper does not propose to delve into the economic efficiency vs public interest debate as that topic has already been covered extensively. ${ }^{17}$ However, within the merger review framework the insertion of section $18 \mathrm{~A}$ fundamentally adds another facet to the above-mentioned tests. It changes the South African merger regime by adding "national security interests" to the list of factors that need to be considered in the review of mergers involving a foreign acquiring firm, thus making it a three-pronged test. It is in this context that the provisions of section $18 \mathrm{~A}$ are discussed and analysed in this paper.

\section{Implications of the insertion of section $18 \mathrm{~A}$ into the Competition Act}

Prior to the amendments to the Competition Act, South Africa had no legal provisions for considering security issues in a merger involving a foreign acquiring firm. Section 14 of the Competition Amendment Act addresses this void by introducing a new section into the Competition Act entitled "Intervention in merger proceedings involving a foreign acquiring firm". Section $18 \mathrm{~A}(1)$ reads as follows:

\footnotetext{
Harmony Gold Mining Co / Gold Fields Ltd [2005] ZACT 29 (18 May 2005) para 44. Sutherland and Kemp Competition Law of South Africa 10-93.

Tavuyanago 2015 GJHSS: E 26.

Hartzenberg "Competition Policy and Enterprise Development"; Lewis "Role of Public Interest in Merger Evaluation" 1-4; Hodge, Goga and Moahloli "Public Interest Provisions in the South African Competition Act" 3-10; Oxenham 2012 US-China L Rev.
} 
The President must constitute a Committee which must be responsible for considering in terms of this section whether the implementation of a merger involving a foreign acquiring firm may have an adverse effect on the national security interests of the Republic.

It is imperative from the outset to define or at least delineate the concept of "national security interests" prior to delving into the intricacies of why it was necessary to codify it and what the implications of such codification are. While section 18A of the Competition Act provides for the intervention in merger proceedings involving a "foreign acquiring firm" based on "national security interests", the terms are not defined. In terms of the section, the President must identify and publish in the Gazette a list of national security interests of the Republic, including the markets, industries, goods or services, sectors or regions in which a merger involving a foreign acquiring firm must be notified to the committee referred to in subsection (1), in terms of subsection (6).

A "foreign acquiring firm" in this context is defined as an acquiring firm which was incorporated, established or formed under the laws of a country other than South Africa; or whose place of effective management is outside the Republic. ${ }^{18}$ The same definition applies in the context of international acquisitions, where it is considered as a firm that is not incorporated in the country where the acquisition is taking place or a firm that has its effective place of business outside the country where the acquisition is taking place. ${ }^{19}$ In determining what constitutes "national security interests" for the purposes of the Act, section $18 \mathrm{~A}(4)$ provides that the President must take into account all relevant factors, including the potential impact of a merger transaction:

- $\quad$ on the Republic's defence capabilities and interests;

- on the use or transfer of sensitive technology or know-how outside of the Republic;

- on the security of infrastructure, including processes, systems, facilities, technologies, networks, assets and services essential to the health, safety, security or economic well-being of citizens and the effective functioning of government;

- $\quad$ on the supply of important goods or services to citizens, or the supply of goods or services to government;

\footnotetext{
18 Meijer 2018 https://www.politicsweb.co.za/politics/on-the-new-competitionamendment-bill.

19 Chen and Hennart 2004 J Bus Res.
} 
- to enable foreign surveillance or espionage, or hinder current or future intelligence or law enforcement operations;

- $\quad$ on the Republic's foreign interests, including foreign relationships;

- to enable or facilitate the activities of illicit actors, such as terrorists, terrorist organisations, or organised crime; and

- $\quad$ on the economic and social stability of the Republic.

The section, however, fails to define or at least describe intelligibly what "national security interests" entail. Instead, the section proffers factors that should be taken into consideration in determining "national security interest". The concept of "national security" is more succinctly described by Cawthra ${ }^{20}$ in the following manner:

\begin{abstract}
National security is the first and most important obligation to government. It involves not just the safety and security of the country and its citizens. It is a matter of guarding national values and interests against both internal and external dangers - threats that have the potential to undermine the security of the state, society and citizens. It must include not just freedom from undue fear of attack against their person, communities or sources of their prosperity and sovereignty, but also the preservation of political, economic and social values - respect for the rule of law, democracy, human rights, a market economy and the environment - which are central to the quality of life in a modern state.
\end{abstract}

The Constitution ${ }^{21}$ also provides an idea of what "national security" aims to achieve:

National security must reflect the resolve of South Africans, as individuals and as a nation, to live as equals, to live in peace and harmony, to be free from fear and want and to seek a better life.

"National security" therefore encompasses social, political and economic interests of the citizens of a country. The right to socio-economic prosperity is one that is implicitly guaranteed and has to be realised in terms of the Constitution of the Republic of South Africa, 1996 (the Constitution). ${ }^{22}$ The protection and realisation of this right, through inclusive participation in the economy is what is envisaged in the preamble to the Competition Act. In light of the above, national security interests should by all means be protected and government must do all it can to ensure the safety and security of its citizens. The addition of section 18A to the Competition Act seems to be in pursuance of government's legitimate duty to protect the

Cawthra "National Security and the Right to Information" 3.

Section 198(a) of the Constitution.

Sections 25, 26 and 27 of the Constitution. 
markets as well as the economic well-being of South Africans. However, the implications of the insertion of section 18A need to be explored and the question of whether the Competition Act is the appropriate medium in which to address the national security interests of the Republic is one that needs to be answered.

\subsection{Challenges posed by the insertion of section $18 \mathrm{~A}$ into the Competition Act}

The insertion of section 18A into the Competition Act, while noble in its purpose, creates a number of challenges with regard to the law. This is evidenced by the strong opposition that the Competition Amendment Act faced in Parliament. ${ }^{23}$ This paper aims to elucidate the potential challenges that the insertion of section $18 \mathrm{~A}$ may pose to the current legal system and the South African community at large. Below is a detailed discussion of the challenges that the insertion of section 18A poses.

\subsubsection{Uncertainty of the Law}

It is cardinal for a system of rules regulating a community to be unambiguous. A legal system that provides legal certainty guides those subject to the law, permits them to plan their lives with less uncertainty and protects them from the arbitrary use of state power. ${ }^{24}$ The first major challenge that the insertion of section 18A poses is that it creates a chasm in the principle of legal certainty. The list of considerations to be taken into account in terms of section $18 \mathrm{~A}(4)$ is too broad and scarcely defined. Van $\mathrm{Dijk}^{25}$ argues that while section $18 \mathrm{~A}$ provides a list to guide the President, the attempt to assist may have achieved the opposite effect by forcing the President to consider a broad concept of "national security" which may be extended to include food security, electricity supply and even job security. The broadness of the list of considerations in section $18 \mathrm{~A}(4)$ creates the inevitability of discord in its interpretation and application, which in turn makes the law uncertain. This broad and uncertain nature of section 18A was also identified and commented on by the Law Society of South Africa ${ }^{26}$ during public hearings, citing that more clarity was needed.

\footnotetext{
23 Phakathi 2018 https://www.businesslive.co.za/bd/national/2018-10-23-parliamentadopts-controversial-competition-amendment-bill/. Maxeiner 2006 Val U L Rev 517.

25 Van Dijk 2018 https://www.financialinstitutionslegalsnapshot.com/2018/08/sapoised-to-follow-suit-in-utilisation-of-non-competition-merger-control-to-protectstate-security-in-foreign-mergers/. PMG 2018 https://pmg.org.za/committee-meeting/26941/.
} 
Further, due to their broad nature the factors are open to the interpretation of the President, the Minister and the national security committee. This is worrying as various interpretations may lead to different outcomes not grounded in law but rather on discretion. As noted by Wood, ${ }^{27}$ much of the content and determinations with regard to section 18A have been left to the President, which content will be published only by regulation and/or in the Government Gazette. This creates a potential challenge with regard to how the section will be applied should there be a merger involving a foreign acquiring firm prior to the clarifications of the section by the President.

The need for legal certainty cannot be understated due to the fact that the stakes in merger policy are so high for the business community, antitrust agencies and for the nation (for economic development and for consumers). ${ }^{28}$ Considering the large number of mergers that are filed every year in South Africa, ${ }^{29}$ the economic costs involved for companies, the costs of litigation where mergers do not comply with filing regulations, the need to attract and retain foreign direct investment through mergers, and the net effect of all the costs being shifted to the consumer, it is imperative that there be precise law regulating mergers in South Africa. In that vein, a law or part of the law that gives power to the President to make political appointments to regulate economic policy based on a broad list of undefined criteria goes against the principle of certainty. It does a great disservice to the investment drive as foreign investors tend to shy away from jurisdictions where the law regulating their investments is uncertain, open to multiple interpretations or can be changed on a whim. This view is supported by Meijer, ${ }^{30}$ who expresses the opinion that this provision (section 18A) is likely to create significant uncertainty for foreign investors and may potentially be a disincentive.

A list of considerations to be taken into account in determining whether there is a threat to national security interests would help create certainty, however, if it were precisely defined or if the national security committee were provided with a clear policy or guideline on what standard they should apply in reaching a decision. I am of the opinion that the list of factors to be taken into consideration should be narrowed down to a closed list of specific areas of strategic national interests that would trigger a review based on

27 Wood $2018 \mathrm{https} / / / \mathrm{www}$. bowmanslaw.com/insights/competition/the-competitionamendment-bill-2018-introduced-in-parliament-national-security-considerations/.

28 Elman 1965 NYU L Rev 613.

29 Over 200 mergers filed in 2018 (Competition Commission Date Unknown http://www.compcom.co.za/merger-and-acquisition-activity-update).

30 Meijer $2018 \mathrm{https} / / /$ www.politicsweb.co.za/politics/on-the-new-competitionamendment-bill. 
national security interests. Further, the national security committee should have set parameters or predetermined terms of reference on which to operate, to ensure that each case is decided in terms of an established policy that is applied consistently.

\subsubsection{Lack of "independence" of the national security committee}

Secondly, there is the question as to the "independence" of the national security committee. While the provision empowers the President to select a committee, it does not provide guidance as to the particular representatives on the committee. ${ }^{31}$ The uncertainty with regard to the composition of the committee as well as its lack of provision for the guarantee of the committee's "independence" raises serious concerns. For the purposes of this discussion, independence entails freedom from control, influence, the sway or the aid of another. Considering the fact that the committee is appointed at the behest of the President with no safeguard against bias, nepotism and partisanship, it would not be irrational to forecast a situation where the committee may be pressured into aligning with a specific political agenda.

A subsection reassuring the independence of the committee drafted in a fashion similar to that of section 181 of the Constitution would have created certainty and allayed any reservations with regard to the issue of the independence of the committee. ${ }^{32}$ The suggestion of the framing of the provision in terms of the aforementioned section 181 is not to say that the committee must be given Chapter 9 status. However, independence as well as mechanisms to test and protect such independence should be expressly provided for.

As it is a committee appointed by the President in a manner similar to that in which the judiciary is constituted, and bearing in mind that no mention is made of the independence of the committee, I would suggest that an approach similar to that of the judiciary should be adopted in addressing the issue of independence. According to Justice Cameron's ${ }^{33}$ paper on Judicial Independence, independence entails both institutional and decisional independence. Institutional independence would mean that the committee enjoys some organisational insulation in a sphere of operation independent

\footnotetext{
31 Wood 2018 https://www.bowmanslaw.com/insights/competition/the-competitionamendment-bill-2018-introduced-in-parliament-national-security-considerations/.

32 Section 181(2) of the Constitution reads: "These institutions are independent, and subject only to the Constitution and the law, and they must be impartial and must exercise their powers and perform their functions without fear, favour or prejudice." Cameron 2010 The Advocate.
} 
of competition authorities, whereas decisional independence would mean that individual members would be able to make their decisions on the facts of the law without pressure or interference. This is in line with judicial independence as provided for in the Constitution. ${ }^{34}$

The national security committee should be held to a standard similar to that of the judiciary, which entails that:

- members must decide on cases free from any outside pressure (economic, personal or political);

- $\quad$ each decision is based on the case at hand and not swayed by the political climate or prevailing foreign policy;

- there should be no tampering with the committee or its jurisdiction for the purposes of controlling its decisions.

The lack of mention of the independence of the committee is unsettling. The drafters of the law failed to take precedent into consideration, specifically section 20 of the Competition Act, justly entitled "Independence of the Competition Commission". Section 20 of the Competition Act provides for the Commission to function without any interference, fear, favour or prejudice, which in turn lends legitimacy and credibility to its work. Specific provision for the committee's independence would have also served to legitimise the idea of the committee, as the legitimacy of antitrust agencies' actions is inherently linked to their ability to act independently and free from external influence either from the companies they supervise or from the state $^{35}$ However, section $18 \mathrm{~A}$ fails to provide a safeguard for the independence of the national security committee, let alone mention such independence. The potential for political interference or bias is thus not addressed. ${ }^{36}$ In the absence of reassurances, foreign investors will not be inclined to invest in an environment where economic policy can easily be tinkered with by those pursuing a specific political agenda. The paper notes that while investors may take on political risk insurance,${ }^{37}$ the unpredictable

\footnotetext{
34 Sections 165(2)-(4) of the Constitution.

35 Alves, Capiau and Sinclair 2015 CL/ 13

36 CliffeDekkerHofmeyr 2019 https://www.cliffedekkerhofmeyr.com/export/sites/cdh/ en/practice-areas/downloads/A-New-Competition-Act.pdf wherein similar sentiments with regard to political interference are noted.

37 See Kagan 2020 https://www.investopedia.com/terms/p/political-risk-insurance.asp; Norton Rose Fullbright Date Unknown https://www.nortonrosefulbright.com/enza/services/f42ed1c3/political-risk-insurance.
} 
environment created due to the lack of independence and the probability of political interference alone could deter would-be investors.

\title{
3.1.3 Lack of accountability of the national security committee
}

The value of accountability can never be overstated. As submitted by Stapenhurst and O'Brien:38

\begin{abstract}
Evaluating the ongoing effectiveness of public officials or public bodies ensures that they are performing to their full potential, providing value for money in the provision of public services, instilling confidence in the government and being responsive to the community they are meant to be serving.
\end{abstract}

Section 18A does not contain any unpretentious provisions for the committee to be accountable to the public, for whose purpose it must be constituted. The only mention of some sort of reporting mechanism is through section $18 \mathrm{~A}(10)$, which provides that the Minister must publish a notice of the committee's decision in the Government Gazette and provide the National Assembly details of the decision. ${ }^{39}$ While this may on the face of it appear like accountability, it is merely an ex post facto reporting mechanism. With regard to the Executive being held accountable for its decisions, a model of oversight of the Executive by the National Assembly exists. ${ }^{40}$ However, the effectiveness of the oversight of the Executive by the National Assembly as envisaged by the Constitution has been under scrutiny lately. ${ }^{41}$ Given the lack/failure of oversight of the Executive, the committee's lack of accountability is a disconcerting possibility.

The fact that the decisions of the committee cannot be influenced, changed or challenged warrants fears of potential abuse. The risk of the potential abuse of the "national security provision" is one captured succinctly by Heinemann: 42

While national security criteria ostensibly serve a legitimate purpose, there is nonetheless a risk that these criteria can be abused by governments who may adopt a broader definition of the concept of 'national security' in order to pursue industrial policy goals.

38 Stapenhurst and O'Brien Date Unknown https://siteresources.worldbank.org/ PUBLICSECTORANDGOVERNANCE/Resources/AccountabilityGovernance.pdf 1.

39 Sections $18 \mathrm{~A}(10)(\mathrm{a})$ and (b) of the Competition Act.

40 Parliament Date Unknown https://www.parliament.gov.za/storage/app/media/ oversight-reports/ovac-model.pdf.

41 See Chirwa and Ntliziywana 2017 https://www.news.uct.ac.za/article/-2017-09-13why-the-peoples-parliament-is-failing-the-people; Mtshali 2019 https://www.iol. co.za/news/politics/statecapture-parliamentary-committees-have-a-case-toanswer-says-expert-25913539; Koza 2019 http://www.702.co.za/articles/ 351362/listen-state-capture-inquiry-to-look-at-parliament-s-oversight-role. Heinemann 2012 JIEL 868-869. 
This is the real risk that South Africa faces, as the list of factors that must be contemplated when considering national security interests is too broad and uncertain. The fact that the interpretation of the factors to be considered in terms of section $18 \mathrm{~A}(4)$ as well as the determination of whether a threat to national security interests exists or not is left to the national security committee, the unfettered intervention powers granted to the Minister of Economic Development as well as the power of the President to delegate any power or function to any cabinet minister in terms of section $18 \mathrm{~A}(15)$ make the potential for abuse of the provision due to lack of accountability not only possible but probable. The abuse of national security is not a fallacy. Of particular note is the ongoing use and abuse of the "national security provision" in the United States of America. President Trump imposed tariffs on a foreign steel manufacturing company in 2018 citing national security concerns, while attempting to protect local steel manufacturers. ${ }^{43}$ President Trump has consistently used national security as a mechanism to protect national industries from competition. ${ }^{44}$ The example of the abuse of the national security provision in the United States of America (USA) is evidence of how a legitimately purposed provision may be used for ulterior agendas.

Furthermore, no avenue is created by the section to challenge or contest a decision made by the committee, thus making it subject to less scrutiny than the competition authorities, for example. Wood notes that the amendment makes no provision for parties' recourse, should they disagree with the outcome of the decision of the Committee. "In light of the framework established, it is likely that parties' recourse may lie outside the jurisdiction of the competition authorities". ${ }^{45}$ This lack of certainty and accountability may foster corruption, which South Africa is no stranger to. Pillay ${ }^{46}$ noted more than a decade ago with regard to corruption in South Africa that:

Corruption is likely to appear on every observer's list of factors that threaten to obstruct South Africa's path towards development. However, rather than diminishing, corruption has proliferated in all segments of the South African national public service, making it the 'common cold' of South African social ills.

Due to the fact that corruption is a scourge that plagues South Africa, as evidenced by the promulgation of laws and the establishment of agencies

\footnotetext{
43 Thrush 2018 https://www.nytimes.com/2018/12/19/us/politics/trump-nationalsecurity-tariffs.html.

44 Lester and Zhu 2019 https://www.cato.org/publications/policy-analysis/closingpandoras-box-growing-abuse-national-security-rationale.

45 Wood 2018 https://www.bowmanslaw.com/insights/competition/the-competitionamendment-bill-2018-introduced-in-parliament-national-security-considerations/.

46 Pillay 2004 IJPSM 586.
} 
aimed at combatting it, ${ }^{47}$ it is again not irrational to foresee corruption plaguing the national security committee due to its lack of transparency and accountability. ${ }^{48}$

It would have been prudent for the drafters of the law to provide a precise "accountability mechanism". An accountability mechanism provides a forum where parties adversely affected by a decision can voice their concerns, report non-compliance or seek redress. A sub-section making the determination of the national security council subject to review by the judiciary or appealable to the Competition Appeal Court would have gone a long way towards ensuring that the committee will be held to account for its actions and decisions.

\subsubsection{Ousting of the competition authorities' authority}

Lastly, the national security committee and its mandate seem to take over the competition authorities' roles, with some critics going so far as to allege a "usurpation of the competition authorities' power by the commission". ${ }^{49}$ The notification of a merger involving a foreign acquiring firm to the committee must simultaneously be made with a notification of the merger to the Commission. ${ }^{50}$ However, where the committee makes a decision to prohibit a merger on national security grounds and the Minister publishes a notice to that effect, the Commission may not make a decision in terms of section $13(5)(b)$ or $14(1)(b),{ }^{51}$ and the Tribunal may not make an order in terms of section 16(2). ${ }^{52}$ The jurisdiction of the competition authorities is automatically ousted in the above instance and there will thus be no consideration of competition grounds and public interest factors. The ordinary merger control process will thus be inhibited.

47 For example, the National Corruption Forum established in 2001, the Prevention and Combating of Corrupt Activities Act 12 of 2004, the South African Police Service's anti-corruption unit and the Specialised Commercial Crimes Court - to prosecute among others, corruption and fraud.

The current investigation by the commission of enquiry into state capture rightly captures the fact that even elected officials who are public servants are not immune to corruption.

Kennedy-Good, Griffiths and Cridlan 2020 https:/www.nortonrosefulbright.com//media/files/nrf/nrfweb/knowledge-pdfs/global-rules-on-foreign-directinvestment/global-rules-on-foreign-direct-investment---south-africa.pdf. Section 18A(6) of the Competition Act.

That is a decision to unconditionally approve, conditionally approve or prohibit the implementation of a merger after consideration in terms of $\mathrm{s} 12 \mathrm{~A}$ of the Competition Act.

Section $18 \mathrm{~A}(12)$ of the Competition Act. That is a decision to unconditionally approve, conditionally approve or prohibit the implementation of a merger after consideration in terms of $\mathrm{s} 12 \mathrm{~A}$ of the Competition Act and the recommendation or request, as the case may be. 
The role of the competition authorities with regard to merger regulation is to ensure fair competition through the consideration of economic efficiency as well as public interest factors. Where the jurisdiction of the competition authorities is automatically ousted through the application of section $18 \mathrm{~A}(12)$, the mandate of the competition authorities cannot be exercised. Section 18(9) provides that during its consideration of a merger in terms of the section, the committee may consult and seek the advice of the Commission or any other relevant regulatory authority. However, the section makes it optional for the authorities to be consulted and thus a decision may be made without any input from the authorities. The lack of a review mechanism of a decision of the national security committee makes the ousting of the jurisdiction of the competition authorities final. Neither the Commission nor the Tribunal can challenge the decision of the national security committee based on competition or public interest grounds. This may further compound investors' apprehensions as the role of competition authorities (ensuring the contestability of markets by removing legal obstacles) may be ousted without review by the national security committee.

Compounding the ousting of the competition authorities' jurisdiction is the lack of a review mechanism where an adverse decision is made by the committee. Van Dijk ${ }^{53}$ warns that this provision is unlikely to pass constitutional muster as it does not provide for participation in the process by the merging parties and does not allow for an appeal of an adverse decision. It would have been judicious to include a provision that allows for the review of the national security council's decisions on petition by a discontented party. This would ensure the constitutionality of the section and send a clear message to investors that the national security council will be held to account, thus bolstering investor confidence in the investment and merger systems.

Having highlighted the challenges to the national security provision, it is necessary to look at the treatment of national security interests in other jurisdictions in order to establish whether South Africa is in line with international best practice. It is also necessary to look to other jurisdictions in view of establishing whether any lessons may be drawn therefrom. The following section discusses the treatment of national security interests in the United States of America, the United Kingdom and Australia.

53 Van Dijk 2018 https://www.financialinstitutionslegalsnapshot.com/2018/08/sapoised-to-follow-suit-in-utilisation-of-non-competition-merger-control-to-protectstate-security-in-foreign-mergers/. 


\section{Treatment of "national security interests" in foreign jurisdictions}

This paper notes that while the addition of section $18 \mathrm{~A}$ to the Competition Act may raise concerns, the review of investments and mergers and acquisitions based on national security is not in itself a new phenomenon. Various countries around the world screen foreign direct investments, including mergers, on the basis of their potential threat to "national security interests". Reader ${ }^{54}$ propounds that national security criteria are widely accepted as legitimate on the basis that they ensure that additional scrutiny is directed at mergers involving firms with assets, operations or geographic locations that are in some way critical to the safety and security of citizens.

\section{1 "National security interests" in the USA, Brazil and Australia}

The ensuing paragraphs provide an overview of how national security interests are treated in three foreign jurisdictions and identify the responsible authorities for the consideration thereof. This will serve a dual purpose. Firstly, it will confirm that the review of investments including mergers and acquisitions based on national security interests is not uncommon. Secondly, it will lay a basis for the analysis of whether competition law is the appropriate forum to address national security interests and whether the Competition Act is the appropriate medium to achieve that goal.

\subsection{1 "National security interests" in the United States of America}

It is imperative to look at the USA as a comparator as it is where anti-trust law was initiated through the promulgation of the Sherman Act. ${ }^{55}$ Furthermore, the American system for vetting foreign takeovers is arguably among the most transparent and institutionalised in the world. ${ }^{56} \mathrm{~A}$ consideration of the American system is therefore cogent as lessons may be drawn therefrom. The USA Defence Production Act ${ }^{57}$ contains a provision titled "authority to review certain mergers, acquisitions and takeovers". In terms of this section, the President of the United States of America has the authority to block or approve a merger, acquisition or takeover based on national security. ${ }^{58}$ The investigation into transactions

Reader 2018 CLI 32.

Munyai Critical Review of Dominant Firms in Competition Law 25-38.

Lenihan Balancing Power without Weapons 34.

Section 721 of the Defence Production Act of 1950 (50 USC App 2170), as amended by the Exon Florio Amendment of 1988 (the Defence Production Act).

58 Section 721(b)(1)(A) read with s 721(d)(1) of the Defence Production Act. 
that may threaten national security interests is mandated to the Committee on Foreign Investment in the United States (CFIUS), which was established in 1975 by President Gerald Ford. ${ }^{59}$

CFIUS is a US federal inter-agency committee chaired by the Secretary of the Treasury. The committee consists of the Secretaries of Homeland Security, Commerce, Defence, State, Energy and Labour, the Attorney General and the Director of National Intelligence, amongst others. ${ }^{60}$ In a bid to tighten the Exon Florio rules, the Foreign Investment National Security Act (FINSA) was enacted. ${ }^{61}$ FINSA has enlarged the scope of the regulation by subjecting the takeover of any "critical infrastructure" or "critical technologies".62 In January 2018 CFIUS blocked the acquisition of MoneyGram by Alibaba, a division of Ant Financial, based on national security interests. The threat to national security was that as US Marines use MoneyGram to remit their earnings to their families, through the acquisition of MoneyGram Alibaba would also acquire the personal details of the Marines and their families. ${ }^{63}$

To offset the potential adverse impact of the investment review process, the USA has a very innovative way of remaining attractive to foreign investors despite its review regime. Section 721(I) of the Defence Production Act makes provision for pre-decision engagement between CFIUS and a potential investor. It provides for "mitigation, tracking and post consummation monitoring" for CFIUS to negotiate, enter into or impose and enforce any agreement or condition with any party to the transaction in question. This assists in mitigating any potential threats to national security and also provides certainty to would-be investors, as they are given feedback and guidelines prior to the commencement of any investment project.

There are two major takeaways from the United States model. First, the consideration of investments and mergers falls under the purview of the Treasury department, which regulates investments in general. The Sherman $A c t,{ }^{64}$ together with the antitrust agencies, ${ }^{65}$ plays no part

$59 \quad$ Georgiev 2008 Yale J on Reg 126.

60 US Department of Treasury Date Unknown https://home.treasury.gov/policyissues/international/the-committee-on-foreign-investment-in-the-united-states-cfius.

$61 \quad$ Foreign Investment and National Security Act of 2007.

62 Heinemann 2012 JIEL 846.

63 McBride and Overman 2018 https://www.bassberrygovcontrade.com/cfiuscontinues-focus-on-information-security-blocks-chinese-acquisition-of-

moneygram/. Competition Act). 
whatsoever when it comes to the consideration of national security interests. Secondly, there is a pre-merger consultative mechanism to ensure that investors are aware of the regulations and comply with them before filing a merger. Such a mechanism if implemented in South Africa would aid the attraction and retention of investors as it would provide certainty and guidance prior to filing, thus eliminating the potential of defective mergers being filed.

\subsection{2 "National security interests" in Brazil}

Brazil was chosen as a comparator to South Africa because both of them are emerging countries and members of BRICS (Brazil, Russia, India, China and South Africa), ${ }^{66}$ in which capacity they focus on economic, political and cultural cooperation, which suggests aligned visions and aspirations. ${ }^{67}$ As a result, there may be various similarities in policies aimed at achieving those aspirations, which makes a comparison of their approaches to national security concerns well founded. Competition law in Brazil is regulated by the Brazilian Competition Act (Law 12.529/2011) ${ }^{68}$ In terms of the Act, merger review falls under the purview of the Administrative Council for Economic Defense (CADE). ${ }^{69}$ CADE is composed of the General Superintendence (GS) which is the first authority to review non-complex mergers, the CADE Tribunal, which considers more complex issues, and the Department of Economic Studies. ${ }^{70}$ Most mergers are decided by the GS of CADE, which may unconditionally approve, conditionally approve or enter into an agreement on merger control with the parties to eliminate the anticompetitive effects of the transaction. ${ }^{71}$

The Brazil Competition Act does not specifically provide for the consideration of national security interests in its merger review framework. However, there are various laws that limit foreign investments in a number of sectors that are considered as critical to the "national security" of Brazil. ${ }^{72}$ Foreign investments regulated by the above-mentioned laws include investments in Brazil by a foreign enterprise through mergers. Brazil imposes a prohibition on investment, including investment through merger,

\footnotetext{
66 See BRICS Brasil 2019 http://brics2019.itamaraty.gov.br/en/about-brics/what-isbrics.

67 BRICS Information Portal date unknown https://infobrics.org/.

68 Zarzur "Brazil" 131-140.

69 Established in terms of Article 5 of Competition Act 12.529/2011.

70 Zarzur "Brazil" 131.

71 Canabrava et al 2020 https://uk.practicallaw.thomsonreuters.com/4-5011911? IrTS=20180530214031634\&transitionType=Default\&contextData=(sc. Defa ult)\&firstPage=true.

72 Stapleton 2015 Wash U L Rev 1671.
} 
in the nuclear, health care, postal services, aerospace, domestic aviation, telecommunications and mining industries, and located in rural areas or near national borders. However, most of the limitations on foreign investment may be lifted upon government authorisation. ${ }^{73}$ Government authorisation for foreign investments in limited industries is granted by the Brazil National Congress (the legislative body of the federal government), with the Conselho de Defesa Nacional (CDN) playing an overarching role in respect of authorisations involving national security interests. ${ }^{74}$ The CDN is a governmental council with the purpose of advising the President about national sovereignty and defence, including creating criteria and conditions for the use of areas indispensable to the national security of Brazil as well as preservation of natural resources. ${ }^{75}$ The CDN comprises of members of the executive branch as well as ministers from various departments, including the Ministers of Justice, the Navy, the Army, Foreign Affairs, the Air Force, and the Economy and Finance. ${ }^{76}$

The major takeaway from the Brazilian model of addressing national security concerns is that merger review is regulated solely by the Brazilian Competition Act and is the responsibility of CADE. The Competition Act does not provide for the consideration of national security matters in the merger review framework. While there are restrictions on foreign investment, including investment through mergers and acquisitions, these restrictions are sector-specific and regulated by sector-specific legislation. Where sector-specific restrictions on foreign investment may be lifted, the Brazilian National Congress is responsible for granting authorisations. The National Congress is the equivalent of the South African Parliament. Giving Parliament the mandate to consider national security interests in various sectors would be prudent as it would increase transparency and limit the risk of corruption and political "arm-twisting".

The CDN, which could be juxtaposed with the national security council in terms of section $18 \mathrm{~A}$, also grants authorisation for prohibited investments, but this is mainly in matters relating to land and the preservation of natural resources. It can be argued that the CDN's primary focus is on national security with regard to political and military matters rather than national security concerns in the economy. If the national security committee were to be established outside the Competition Act and were to focus on the threat to national security specifically relating to the country's military

Stapleton 2015 Wash U L Rev 1672.

Stapleton 2015 Wash U L Rev 1672.

Article 91 of the Constitution of the Federative Republic of Brazil, 1988.

Stapleton 2015 Wash U L Rev 1673. 
capabilities, the preservation of natural resources and the protection of land adjacent to South Africa's borders, its mandate would be similar to the that of the CDN and thus more palatable.

\subsection{3 "National security interests" in Australia}

Australia is another jurisdiction with a merger regime similar to South Africa's and that specifically provides for the investigation and consideration of national security interests in relation to foreign direct investment, including mergers. This makes it an ideal comparator, as there are lessons to be learnt from its treatment of national security in transactions involving foreign firms. Australia has specific legislation speaking to the issue of foreign investment and ensuring certainty with regard to Australian investment policy. ${ }^{77}$

Australia's foreign investment policy is administered by the Treasurer, who also has the authority to either block or approve a transaction with or without conditions based on national security interests. ${ }^{78}$ The Foreign Acquisitions and Takeovers Act (FATA) also provides legal certainty as it provides a threshold for transactions that must be investigated and approved by the Treasurer, who is assisted in the investigation and decision-making process by the Foreign Investment Review Board (FIRB). ${ }^{79}$ The FIRB is a nonstatutory advisory body, whose functions include fostering an awareness, both in Australia and abroad, of the Government's foreign investment policy and providing guidance where necessary to foreign investors so that their proposals conform with the policy. ${ }^{80}$ While Australia is not alien to reviewing foreign investments, including mergers based on "national security interests", the task is left to the treasury on a purely investment and economic basis. The competition authorities have no input into the approval or non-approval of foreign investment based on national security interests.

The major takeaway from the Australian regime is the establishment of the Foreign Investment Review Board. The board assists investors in acquainting themselves with the law as it relates to mergers and takeovers, thus equipping them to make informed decisions when it comes to the

\footnotetext{
77 The Foreign Acquisitions and Takeovers Act of 1975, as amended.

78 Treasury Australia Date Unknown https://treasury.gov.au/publication/makingtransparency-transparent-an-australian-assessment/chapter-3-foreign-directinvestment-policy/.

79 FIRB Date Unknown http://firb.gov.au. Also see Sawyer and Johnson 2007 Corporate Ownership and Control 345.

80 Treasury Australia Date Unknown https://treasury.gov.au/publication/makingtransparency-transparent-an-australian-assessment/chapter-3-foreign-directinvestment-policy/.
} 
Australian review of foreign investment, including mergers and takeovers. The idea informing the establishment of the board, that of awareness and transparency, is similar to the pre-notification arrangement available to investors in the USA. Lessons with regard to having specific institutions dedicated to the consideration of national security interests as well as engagement with foreign firms prior to a merger can be drawn from both the USA and Australia.

While this paper argues that security considerations have been misplaced through the insertion of section $18 \mathrm{~A}$ into the Competition Act, in the current form in which the consideration of national security interests is provided for, it would do South Africa a great service either to establish a body similar to the FIRB, empowering the Commission to engage in pre-merger discussions with foreign firms or to allow for the negotiation and conclusion by the national security committee of pre-merger settlements with regard to mergers that potentially threaten national security, as is the case in the USA.

\subsection{Analysis of the treatment of "national security interests" in foreign jurisdictions}

From the above discussion on the treatment of national security interests in the USA, Brazil and Australia it is clear that competition authorities have little to no input into the consideration of investments, including mergers, based national security interests. Rather, the trend seems to be that national security interests are addressed through "investment screening" by the respective treasuries, committees or investment review bodies. Investment screening is the process of determining which investments to allow or exclude based on a number of factors. Most countries will have a screening mechanism, which is a mechanism allowing the State to monitor foreign investments in companies or sectors considered of strategic importance and to oppose them under certain conditions. It is evident that investment screening is becoming more ubiquitous, with the announcement of the European Commission's new framework for screening foreign direct investment ${ }^{81}$ and section $18 \mathrm{~A}$ of the Competition Act.

It can thus be argued that South Africa's decision to regulate foreign investment in the form of mergers involving a foreign acquiring firm based on national security interests is neither novel nor protectionist. Investment screening as illustrated above is commonplace in foreign jurisdictions, as it is deemed necessary for the protection and preservation of the national

81 European Commission 2019 https://eur-lex.europa.eu/legal-content/EN/TXT/ ?uri=CELEX\%3A32019R0452\&qid=1603891018358. 
economy. Furthermore, the consideration of whether a certain transaction involving a foreign acquiring firm may threaten national security interests is in pursuance of the spirit and purport of the Constitution. ${ }^{82}$ It is government's obligation to ensure the safety and security of its citizens and in doing so, government must fervently defend and protect the national security interests of the country. Consequently, it is my view that the introduction of investment screening based on national security interests is an imperative and is in line with international best practice. Having said that, the consideration and implementation of screening based on "national security interests" ought to be mandated to a relevant body. This raises the question whether competition law is the appropriate platform to address national security interests.

\subsection{Is competition law the appropriate medium for addressing national security interests?}

Due to the expansion of digital communications as well as the advent of cross-border transactions, the protection of national security has never been more imperative. As noted above, it is government's legitimate purpose to protect national security. I would argue, however, that competition law is not the appropriate platform to address screening based on national security interests given the fact that the goal of competition law and the primary goal of the Competition Act is the promotion and maintenance of competition. ${ }^{83}$

The screening of investments, including investments through mergers and acquisitions based on national security interests, should be done through a coherent national security policy. National Security Policy (NSP) is a framework for describing how a country provides security for the state and its citizens, and is often presented as an integrated document. However, South Africa does not have an integrated national security policy despite having an agency specifically tasked with the promotion and protection of national security interests. ${ }^{84}$ Absent a coherent and harmonious national security policy, the protection of national security interests becomes piecemeal, being regulated and implemented through different forums.

What we see with the addition of section 18A of the Competition Act is an attempt to introduce and implement a national security policy through competition law. While it is accepted that where no stand-alone policy exists, space may be made in different, relevant legislation to address such a gap, but one would argue that the insertion of section 18A into the

Section 198 of the Constitution.

Jordaan and Munyai 2011 SA Merc LJ 198.

State Security Agency Date Unknown http://www.ssa.gov.za/. 
Competition Act muddles the objectives of competition law. While government may legitimately intervene in various sectors on matters of national security interest, as is the case in the jurisdictions discussed above, mergers should continue to be regulated in a manner consistent with the objectives of enhancing competition, albeit tempered with considerations of public interest. I am of the opinion that were there a coherent national security policy codified in legislation, which in terms of a hierarchy would rank above all industry-specific legislation, there would be no problem with a national security committee's reviewing decisions of the competition authorities based on national security grounds as part of a broader and definite national security policy.

In debates held on the insertion of a national security interest clause into the Competition Act, the Minister of Economic Development acknowledged that the protection of national security where a foreign firm was involved could be dealt with in one of three ways:

- $\quad$ through competition law;

- through investment law; or

- through stand-alone legislation. ${ }^{85}$

It is submitted that it would have been more appropriate to have stand-alone legislation regulating national security interests. According to the Minister, one of the pros of stand-alone legislation would have been its ability to "go beyond mergers such as when a foreign firm is acquiring a business overlooking a national key point, thus falling outside the scope of competition." 86 This seems more favourable as it would have established some coherent reference point with regard to matters of national security generally, instead of having it regulated spasmodically. On consideration of regulating national security interests through investment laws, the definition of "investment" in terms of the Protection of Investment Act (PIA) includes mergers and acquisitions. ${ }^{87}$ If one considers the treatment of national security interests in the USA, Brazil and Australia it is clear that the consideration of national security interests as they relate to mergers was partially already provided for through the PIA. The purpose of the PIA is to:88

PMG 2018 https://pmg.org.za/committee-meeting/27045/.

PMG 2018 https://pmg.org.za/committee-meeting/27045/.

Section 2(1) of the Protection of Investment Act 22 of 2015 (hereafter PIA).

Section 4 of the PIA. 
(a) protect investment in accordance with and subject to the Constitution, in a manner that balances the public interest and the rights and obligations of investors;

(b) affirm the Republic's sovereign right to regulate investments in the public interest; and

(c) confirm the Bill of Rights in the Constitution and the laws that apply to all investors and their investment in the Republic.

Section 4(b) of PIA is of particular import as it clearly entrenches the government's right to regulate investment (including mergers and acquisitions), which in my opinion includes the right to screen foreign investment based on national security interests. Furthermore, section 5 provides that the Act applies to all investments as defined in section 2, which definition includes mergers and acquisitions. The government or any organ of state may take measures that are necessary for the fulfilment of the Republic's obligations in regard to the maintenance off, compliance with or restoration of international peace and security, or the protection of security interests, including the financial stability of the Republic. ${ }^{89}$

Considering the above provisions of the PIA, it would seem logical and indeed judicious to specifically provide for investment screening through legislation that is specifically promulgated to regulate investments. A better platform for the consideration of national security interests would have been under section 12 of the PIA as section 12(2) broaches the subject. It would have been ideal to amend or expand the provision and include national security therein as acknowledged by the Minister, and for the legislature not to use the Competition Act as a stopgap mechanism.

\section{Conclusion}

This paper has observed that investment screening based on national security interests is becoming more and more conventional and South Africa's decision to pursue a similar policy is not, in my view, isolationist. The intention of section 18A seems to give effect to government's constitutional responsibility with regard to national security as outlined in section 198 of the Constitution. As emphatically expressed by Malatji: 90

Every country has a right to protect its national security interests and sovereignty, considering the prevalence of global terrorism and national security breaches. Section $18 \mathrm{~A}$ ensures that foreign companies enter the

89 Section 12(2) of the PIA.

90 Malatji Kanyane Attorneys 2018 http://pmg-assets.s3-website-eu-west1.amazonaws.com/180828MKINC.pdf. 
domestic market purely for commercial reasons and contribute positively to the national economy.

Whereas Malatji is correct with regard to the protection of national security and while the spirit of the legislation may be in line with constitutional provisions, the introduction of a national security provision through the Competition Act is misplaced, as the Competition Act is not in my view the appropriate contrivance to address issues of investment screening. I am in agreement with Wood ${ }^{91}$ insofar as he notes that a separate decision-making body and stand-alone process from the existing merger control regime, which may appear quite foreign in the context of the current Act, would make sense, as it is inappropriate to burden the competition merger review process with national security assessments. I would go even further and say that an independent decision-making body should have been provided for under the PIA alternatively, in a stand-alone Act. It is imperious that national security interests be protected by all means. However, there is a need to ensure national security without alienating foreign investment. To this end, there needs to be a specific, clearly defined trade and investment policy instead of the piecemeal application of investment screening, which could be achieved by amending the PIA accordingly or coming up with a standalone piece of legislation on national security. This would create certainty and transparency, which in turn would ensure that South Africa remains attractive to foreign direct investment and investments through mergers.

Outside the realms of their competition regimes, many countries have also incorporated national security criteria in a separate foreign direct investment review process, which enables governments to evaluate not only mergers but also broader types of investments. ${ }^{92}$ I am in full agreement with the aforementioned viewpoint and would argue that South Africa does indeed have the appropriate medium to address investment screening. The most appropriate avenue to regulate trade and investment and by implication conduct investment screening, is through the Protection of Investment Act. In the alternative, a stand-alone piece of legislation covering national security concerns would also be welcome. Stand-alone legislation would provide a wider catchment ranging from national security concerns in competition to national security concerns in investment.

In conclusion, an amendment to the Protection of Investment Act introducing investment screening, including screening of mergers as well as addressing the challenges highlighted by this paper, should be considered

91 Wood $2018 \mathrm{https} / / /$ www.bowmanslaw.com/insights/competition/the-competitionamendment-bill-2018-introduced-in-parliament-national-security-considerations/.

92 Reader 2018 CLI 32. 
by the legislature. In the alternative, and only insofar as it relates to national security concerns, the legislature should consider a National Security Act, which would regulate national security concerns across various areas such as competition, investment and cyber security. The legislature could have taken more time in drafting a more comprehensive Act, as implied by CliffeDekkerHofmeyr. ${ }^{93}$ This paper's submission is that competition law has no business regulating national security in trade and investment when there is specific legislation, or there should be specific legislation, enacted for that purpose. In my view, the approach should be as simple as the titles of the Acts suggests. The Competition Act should regulate competition policy while the Protection of Investment Act should regulate investment policy, including investment screening based on national security interests.

\section{Bibliography}

\section{Literature}

Alves, Capiau and Sinclair 2015 CLI

Alves S, Capiau J and Sinclair A "Principles for the Independence of Competition Authorities" 2006 CLI 13-27

Brassey et al Competition Law

Brassey M et al Competition Law (Juta Cape Town 2002)

Cameron 2010 The Advocate

Cameron E "Judicial Independence - A Substantive Component?" 2010 The Advocate 24-29

Cawthra "National Security and the Right to Information" Cawthra G "National Security and the Right to Information: The Case of South Africa" Unpublished contribution delivered at the Southern African Consultative Conference on National Security and Right to Information Principles (26 February 2013 Johannesburg)

Chen and Hennart $2004 \mathrm{~J}$ Bus Res

Chen SFS and Hennart JFH "A Hostage Theory of Joint Ventures: Why Do Japanese Investors Choose Partial over Full Acquisitions to Enter the United States?" 2004 J Bus Res 1126-1134

93 CliffeDekkerHofmeyr 2019 https://www.cliffedekkerhofmeyr.com/export/sites/cdh/ en/practice-areas/downloads/A-New-Competition-Act.pdf. 
EIman 1965 NYU L Rev

Elman $\mathrm{P}$ "The Need for Certainty and Predictability in the Application of the Merger Law" 1965 NYU L Rev613-627

Georgiev 2008 Yale J on Reg

Georgiev S "The Reformed CFIUS Regulatory Framework: Mediating between Continued Openness to Foreign Investment and National Security" 2008 Yale J on Reg 125-134

Hartzenberg 2006 NWJILB

Hartzenberg $\mathrm{T}$ "Competition Policy and Practice in South Africa: Promoting Competition for Development" 2006 NWJILB 667-686

Hartzenberg "Competition Policy and Enterprise Development" Hartzenberg $\mathrm{T}$ "Competition Policy and Enterprise Development: The Role of Public Interest Objectives in South Africa's Competition Policy" in Cook P, Fabella RV and Lee C (eds) Competitive Advantage and Competition Policy in Developing Countries (Edward Elgar Cheltenham 2007) ch 8

Heinemann 2012 JIEL

Heinemann A "Government Control of Cross-Border M\&A: Legitimate Regulation or Protectionism?" 2012 JIEL 843-870

Hodge, Goga and Moahloli "Public Interest Provisions in the South African Competition Act" Hodge J, Goga S and Moahloli T "Public Interest Provisions in the South African Competition Act - A Critical Review" Unpublished contribution delivered at the Competition Policy, Law and Economics Conference (2009) 3-10

Jordaan and Munyai 2011 SA Merc LJ

Jordaan L and Munyai PS "The Constitutional Implications of the New Section 73A of the Competition Act 89 of 1998" 2011 SA Merc LJ 197-213

Lenihan Balancing Power without Weapons

Lenihan AT Balancing Power without Weapons: State Intervention into Cross-border Mergers and Acquisitions (Cambridge University Press Cambridge 2018) 
Lewis "Role of Public Interest in Merger Evaluation"

Lewis D "The Role of Public Interest in Merger Evaluation" Unpublished contribution delivered at the International Competition Network Merger Working Group Conference (28-29 September 2002 Naples) 1-4

Maxeiner $2006 \mathrm{Val} U L \mathrm{ReV}$

Maxeiner JR "Legal Indeterminacy Made in America: US Legal Methods and the Rule of Law" 2006 Val U L Rev 517-589

Munyai Critical Review of Dominant Firms in Competition Law Munyai PS A Critical Review of Dominant Firms in Competition Law: A Comparative Study (LLD-thesis University of South Africa 2016)

Munyai 2017 De Jure

Munyai PS "Claims for Damages Arising from Conduct Prohibited under the Competition Act 1998" 2017 De Jure 18-35

Nyali and Wood "South Africa"

Nyali X and Woods S "South Africa" in Gotts IK (ed) The Merger Control Review $11^{\text {th }}$ ed (Law Business Research Ltd London 2020) 309-319

Oxenham 2012 US-China L Rev

Oxenham J "Balancing Public Interest Merger Considerations before Sub-Saharan African Competition Jurisdictions with the Quest for Multi-jurisdictional Merger Control Certainty" 2012 US-China L Rev 211-227

Pillay 2004 IJPSM

Pillay S "Corruption - The Challenge to Good Governance: A South African Perspective" 2004 IJPSM 586-605

Reader 2018 CLI

Reader DM "Extending National Security in Merger Control and Investment: A Good Deal for the UK?" 2018 CL/ 35-52

Sawyer and Johnson 2007 Corporate Ownership and Control Sawyer KR and Johnson J "Does the National Interest Matter? A Case Study of a Cross-border Merger" 2007 Corporate Ownership and Control 345-356 
Stapleton 2015 Wash U L Rev

Stapleton C "The Global Colony: A Comparative Analysis of National Security-based foreign Investment Regimes in the Western Hemisphere" 2015 Wash U L Rev 1647-1681

Sutherland and Kemp Competition Law of South Africa

Sutherland $\mathrm{P}$ and Kemp K Competition Law of South Africa (LexisNexis Butterworths Durban 2000)

Tavuyanago 2015 GJHSS: E

Tavuyanago $S$ "Public Interest Considerations and their Impact on Merger Regulation in South Africa" 2015 GJHSS: E 23-43

Zarzur "Brazil"

Zarzur CS "Brazil" in Gotts IK (ed) The Merger Control Review $7^{\text {th }}$ ed (Law Business Research Ltd London 2016) 131-140

\section{Case law}

Harmony Gold Mining Co / Gold Fields Ltd [2005] ZACT 29 (18 May 2005)

\section{Legislation}

\section{Australia}

Foreign Acquisitions and Takeovers Act of 1975

\section{Brazil}

Competition Act 12.529/2011

Constitution of the Federative Republic of Brazil, 1988

\section{South Africa}

Competition Act 89 of 1998

Competition Amendment Act 18 of 2018

Constitution of the Republic of South Africa, 1996

Prevention and Combating of Corrupt Activities Act 12 of 2004

Protection of Investment Act 22 of 2015 


\section{United States of America}

Defence Production Act of 1950 (50 USC App 2170)

Foreign Investment and National Security Act of 2007

Sherman Anti-Trust Act of 1890

\section{Internet sources}

BRICS Brasil 2019 http://brics2019.itamaraty.gov.br/en/about-brics/whatis-brics

BRICS Brasil 2019 What is BRICS? http://brics2019.itamaraty. gov.br/en/about-brics/what-is-brics accessed 21 October 2020

BRICS Information Portal date unknown https://infobrics.org/ BRICS Information Portal date unknown What is the BRICS? https://infobrics.org/ accessed 21 October 2020

Canabrava et al 2020 https://uk.practicallaw.thomsonreuters.com/4-5011911? IrTS=20180530214031634\&transitionType=Default\&contextData= (sc. Default)\&firstPage $=$ true

Canabrava et al 2020 Merger Control in Brazil: Overview https://uk.practicallaw.thomsonreuters.com/4-5011911?_IrTS=20180530214031634\&transitionType=Default\&conte xtData $=($ sc.Default)\&firstPage $=$ true accessed 21 October 2020

Chirwa and Ntliziywana 2017 https://www.news.uct.ac.za/article/-2017-0913-why-the-peoples-parliament-is-failing-the-people

Chirwa D and Ntliziywana P 2017 Why the People's Parliament is Failing the People https://www.news.uct.ac.za/article/-2017-09-13why-the-peoples-parliament-is-failing-the-people accessed 10 January 2020

CliffeDekkerHofmeyr 2019 https://www.cliffedekkerhofmeyr.com/export/ sites/cdh/en/practice-areas/downloads/A-New-Competition-Act.pdf CliffeDekkerHofmeyr 2019 A New Competition Act https://www.cliffedekkerhofmeyr.com/export/sites/cdh/en/practiceareas/downloads/A-New-Competition-Act.pdf accessed 30 October 2020 
Competition Commission Date Unknown http://www.compcom.co.za/ merger-and-acquisition-activity-update Competition Commission Date Unknown Merger and Acquisition Activity Update http://www.compcom.co.za/merger-and-acquisitionactivity-update accessed 29 January 2020

European Commission 2019 https://eur-lex.europa.eu/legalcontent/EN/TXT/?uri=CELEX\%3A32019R0452\&qid=1603891018358 European Commission 2019 Regulation (EU) 2019/452 of the European Parliament and the Council of 19 March 2019 Establishing a Framework for the Screening of Foreign Direct Investments into the Union https://eur-lex.europa.eu/legal-content/EN/TXT/?uri=CELEX \%3A32019R0452\&qid=1603891018358 accessed 28 October 2020

Federal Trade Commission Date Unknown https://www.ftc.gov/enforcement Federal Trade Commission Date Unknown Enforcement https://www.ftc.gov/enforcement accessed 7 February 2019

FIRB Date Unknown http://firb.gov.au

Foreign Investment Review Board Date Unknown Home Page http://firb.gov.au accessed 7 February 2019

Helen Suzman Foundation 2018 https://hsf.org.za/publications/hsfbriefs/parliamentary-submission-competition-amendment-bill-2018 Helen Suzman Foundation 2018 Response to Competition Amendment Bill - Parliamentary Submission: Competition Amendment Bill, 2018 https://hsf.org.za/publications/hsfbriefs/parliamentary-submission-competition-amendment-bill-2018 accessed 9 October 2019

Kagan $2020 \quad$ https://www.investopedia.com/terms/p/political-riskinsurance.asp

Kagan J 2020 Political Risk Insurance https://www.investopedia.com/terms/p/political-risk-insurance.asp accessed 30 October 2020

Kennedy-Good, Griffiths and Cridlan 2020 https://www.nortonrosefulbright.com/-/media/files/nrf/nrfweb/knowledgepdfs/global-rules-on-foreign-direct-investment/global-rules-on-foreigndirect-investment---south-africa.pdf Kennedy-Good S, Griffiths M and Cridlan D 2020 South Africa COVID-19 Crisis Inspires Global Tightening of Foreign Investment Screening https://www.nortonrosefulbright.com/-/media/files/nrf/ 
nrfweb/knowledge-pdfs/global-rules-on-foreign-directinvestment/global-rules-on-foreign-direct-investment---southafrica.pdf accessed 20 October 2020

Koza 2019 http://www.702.co.za/articles/351362/listen-state-captureinquiry-to-look-at-parliament-s-oversight-role Koza N 2019 State Capture Inquiry to Look at Parliament's Oversight Role http://www.702.co.za/articles/351362/listen-state-captureinquiry-to-look-at-parliament-s-oversight-role accessed 30 October 2020

Lester and Zhu 2019 https://www.cato.org/publications/policyanalysis/closing-pandoras-box-growing-abuse-national-security-rationale Lester S and Zhu H 2019 Closing Pandora's Box: The Growing Abuse of the National Security Rationale for Restricting Trade https://www.cato.org/publications/policy-analysis/closing-pandorasbox-growing-abuse-national-security-rationale accessed 10 January 2020

Malatji Kanyane Attorneys 2018 http://pmg-assets.s3-website-eu-west1.amazonaws.com/180828MKINC.pdf

Malatji Kanyane Attorneys 2018 Comments on the Competition Amendment Bill B23-2018 http://pmg-assets.s3-website-eu-west.amazonaws.com/180828MKINC.pdf accessed 10 January 2020

McBride and Overman 2018 https://www.bassberrygovcontrade.com/cfiuscontinues-focus-on-information-security-blocks-chinese-acquisition-ofmoneygram/

McBride T and Overman T 2018 CFIUS Continues Focus on Information Security, Blocks Chinese Acquisition of MoneyGram https://www.bassberrygovcontrade.com/cfius-continues-focus-oninformation-security-blocks-chinese-acquisition-of-moneygram/ accessed 9 November 2018

Meijer 2018 https://www.politicsweb.co.za/politics/on-the-new-competitionamendment-bill

Meijer J 2018 On the New Competition Amendment Bill: New Competition Amendment Bill Gives Govt the Right to Block Foreign Investments in SA https://www.politicsweb.co.za/politics/on-thenew-competition-amendment-bill accessed 30 January 2020

Mtshali $2019 \quad$ https://www.iol.co.za/news/politics/statecaptureparliamentary-committees-have-a-case-to-answer-says-expert-25913539 
Mtshali S 2019 State Capture: Parliamentary Committees have a Case to Answer https://www.iol.co.za/news/politics/statecaptureparliamentary-committees-have-a-case-to-answer-says-expert25913539 accessed 30 October 2020

Norton Rose Fullbright Date Unknown https://www.nortonrosefulbright.com/en-za/services/442ed1c3/political-riskinsurance

Norton Rose Fullbright Date Unknown Political Risk Insurance https://www.nortonrosefulbright.com/en-

za/services/442ed1c3/political-risk-insurance accessed 30 October 2020

Parliament Date Unknown https://www.parliament.gov.za/ storage/app/media/oversight-reports/ovac-model.pdf

Parliament of the Republic of South Africa Date Unknown Oversight and Accountability Model Asserting Parliament's Oversight Role in Enhancing Democracy https://www.parliament.gov.za/storage/ app/media/oversight-reports/ovac-model.pdf accessed 30 October 2020

Phakathi 2018 https://www.businesslive.co.za/bd/national/2018-10-23parliament-adopts-controversial-competition-amendment-bill/ Phakathi B 2018 Parliament Adopts Controversial Competition Bill https://www.businesslive.co.za/bd/national/2018-10-23-parliamentadopts-controversial-competition-amendment-bill/ accessed 18 January 2019

PMG 2018 https://pmg.org.za/committee-meeting/26941/

Parliamentary Monitoring Group 2018 Competition Amendment Bill: Public Hearings Day 1 https://pmg.org.za/committee-meeting/26941/ accessed 9 October 2019

PMG 2018 https://pmg.org.za/committee-meeting/27045/

Parliamentary Monitoring Group 2018 Competition Amendment Bill B23-2018: Ministry Response to Submissions https://pmg.org.za/committee-meeting/27045/ accessed 10 January 2020

Stapenhurst and O'Brien Date Unknown https://siteresources.worldbank.org/PUBLICSECTORANDGOVERNANCE/ Resources/AccountabilityGovernance.pdf 
Stapenhurst $\mathrm{R}$ and O'Brien M Date Unknown Accountability in Governance https://siteresources.worldbank.org/PUBLICSECTORANDGOVERN ANCE/Resources/AccountabilityGovernance.pdf accessed 18 January 2019

State Security Agency Date Unknown http://www.ssa.gov.za/ State Security Agency Date Unknown Vision and Mission http://www.ssa.gov.za/ accessed 11 November 2018

Thrush 2018 https://www.nytimes.com/2018/12/19/us/politics/trumpnational-security-tariffs.html

Thrush G 2018 Trump's Use of National Security to Impose Tariffs Faces Court Test https://www.nytimes.com/2018/12/19/us/ politics/trump-national-security-tariffs.html accessed 10 January 2020

Treasury Australia Date Unknown https://treasury.gov.au/publication/ making-transparency-transparent-an-australian-assessment/chapter-3foreign-direct-investment-policy/ Treasury Australia Date Unknown Foreign Direct Investment Policy https://treasury.gov.au/publication/making-transparencytransparent-an-australian-assessment/chapter-3-foreign-directinvestment-policy/ accessed 9 November 2018

US Department of Treasury Date Unknown https://home. treasury.gov/policy-issues/international/the-committee-on-foreigninvestment-in-the-united-states-cfius US Department of Treasury Date Unknown Overview of CFIUS Process https://home.treasury.gov/policy-issues/international/thecommittee-on-foreign-investment-in-the-united-states-cfius accessed 16 January 2019

Van Dijk 2018 https://www.financialinstitutionslegalsnapshot.com/ 2018/08/sa-poised-to-follow-suit-in-utilisation-of-non-competition-mergercontrol-to-protect-state-security-in-foreign-mergers/

Van Dijk J 2018 SA Poised to Follow Suit in Utilisation of Noncompetition Merger Control to Protect State Security in Foreign Mergers https://www.financialinstitutionslegalsnapshot.com/2018/ 08/sa-poised-to-follow-suit-in-utilisation-of-non-competition-mergercontrol-to-protect-state-security-in-foreign-mergers/ accessed 20 October 2020 
Wood 2018 https://www.bowmanslaw.com/insights/competition/thecompetition-amendment-bill-2018-introduced-in-parliament-nationalsecurity-considerations/

Wood S 2018 The Competition Amendment Bill, 2018 Introduced in Parliament: National Security Considerations https://www.bowmanslaw.com/insights/competition/the-competitionamendment-bill-2018-introduced-in-parliament-national-securityconsiderations/ accessed 19 January 2020

\section{List If Abbreviations}

$\begin{array}{ll}\text { BRICS } & \begin{array}{l}\text { Brazil, Russia, India, China and South Africa } \\ \text { CAdministrative Council for Economic } \\ \text { Defense }\end{array} \\ \text { CDN } & \begin{array}{l}\text { Conselho de Defesa Nacional } \\ \text { Committee on Foreign Investment in the } \\ \text { United States } \\ \text { CFIUS }\end{array} \\ \text { Competition Law International } \\ \text { FLI } & \text { Foreign Acquisitions and Takeovers Act } \\ \text { FATA } & \text { Foreign Investment National Security Act } \\ \text { FINSA } & \text { Foreign Investment Review Board } \\ \text { FIRB } & \text { Global Journal of Human Social Sciences: } \\ \text { GJHSS: E } & \text { Economics } \\ \text { GS } & \text { General Superintendence } \\ \text { IJPSM } & \text { International Journal of Public Sector } \\ \text { J Bus Res } & \text { Management } \\ \text { JIEL } & \text { Journal of Business Research } \\ \text { NSP } & \text { Journal of International Economic Law } \\ \text { NWJILB } & \text { National Security Policy } \\ \text { NYU L Rev } & \text { Northwestern Journal of International Law } \\ \text { PIA } & \text { and Business } \\ \text { PMG } & \text { New York University Law Review } \\ \text { SA Merc LJ } & \text { Protection of Investment Act } \\ \text { US / USA } & \text { Parliamentary Monitoring Group } \\ \text { US-China L Rev } & \text { South African Mercantile Law Journal } \\ \text { Val U L Rev } & \text { United States of America } \\ \text { Wash U L Rev } & \text { US-China Law Review } \\ \text { Yale J on Reg } & \text { Valparaiso University Law Review } \\ & \text { Washington University Law Review } \\ & \text { Yale Journal on Regulation }\end{array}$

